\title{
Understand Bearing Habit in Mango
}

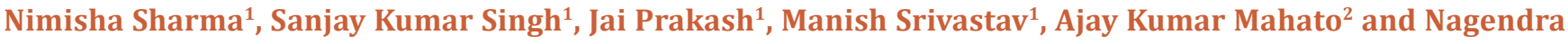 \\ Kumar Singh² \\ ${ }^{1}$ Division of Fruits and Horticultural Technology, ICAR-Indian Agricultural Research Institute, India \\ ${ }^{2}$ ICAR- National Research Centre on Plant Biotechnology, New Delhi, India
}

Submission: August 03, 2017; Published: August 21, 2017

*Correspondingauthor: Nimisha Sharma, Scientist, IARI, New Delhi, India, Email: nims17sharma@gmail.com

\section{Introduction}

India is the major producer of various fruit crops like mangoes, banana, citrus, etc. In the world, although it's relative share in the world production has been gradually declining. The decline in production is attributed not only due to the incidence of pests and diseases, but also influenced by other factors like poor germination percentage, lack of efficient rootstocks, irregular bearing etc. Alternate bearer fruit cultivars present a serious economic problem to fruit growers. During a good year, a tree can be loaded with bumper yield; however, crop quality fluctuates from year to year, so that in the year following a good crop, there are relatively few fruits which affect the overall crop production [1]. The bearing behaviour of a crop can be affected by the environmental conditions, cultivars, rootstocks, and management. Phenomenon of alternation is more prominent in the perennial fruit crops particularly Anacardiaceae (Mango, Pistachionut), Carylaceae (Hazelnut), Oleaceae (Olives), Rosaceae (Apple, Pear, Plum, Apricot etc.), Rutaceae (Orange, Tangor, Satsuma etc.,) and also in tamarind and Jamun etc. Various research workers throughout the world have studied the phenomenon of alternate bearing in different fruit crops and associated several horticultural traits with this complex phenomenon.

\section{Alternate Bearing in Mango}

Similarly, the flowering phenomenon in mango is a complex one. Normally, it crops heavily in one year (on year) and bears less or no crop the following year (off year). Again, it yields heavily the next year. The term biennial, alternate or irregular bearing generally signifies the tendency of mango trees to bear a heavy crop in one year (On year) and very little or no crop in the succeeding year (Off year).

\section{Impact of Various Factors on Bearing of Mango}

Research findings have clearly indicated that this phenomenon is mostly due to varietal and varieties with axillary fruit bearing habit posses less than terminal bearing. Most of the commercial varieties of North India, namely, Dashehari, Langra and Chausa are biennial bearers, while south Indian varieties like Totapuri Red Small, Bangalora, and Neelum are known to be regular bearers. Among the most important commercial varieties of the South, Neelum (Kazaladdu), Banganapalli (Sappatai), Bangalora (Kizhimooku, Totapuri) Kalepad and Senthura (Chinnaswarnarekha) are moderate to heavy bearers and are considered to be fairly regular. Choice varieties such as Alphonso (Gundu), Imam Pasand (Himayuddin), Mulgoa, Peter (Pairi, Nadusalai) etc., are mostly erratic in bearing.

When a tree produces heavy crop in one season, it gets exhausted nutritionally and is unable to put forth new flush thereby failing to yield in the following season. Draining out of $\mathrm{CHO}$ and $\mathrm{N}$ reserves during "on" year is known to lead to a lean crop in the "off "year as they are important for fruit bud initiation i.e. high $\mathrm{C} / \mathrm{N}$ ratio helps for fruit bud initiation. As per physiological studies in regular and irregular varieties of mango indicated that mesophyll cells in leaves of the regular mango varieties are more uniform and highly efficient in $\mathrm{CO} 2$ utilization [2].

The problem has been attributed to the causes like genetical, physiological, environmental and nutritional factors. The behavior could be due to plant hormones, particularly gibberellins produced in excess in the "on" years in the embryos of the young fruit. Thus the rhythm of bearing in mango is not strictly 'alternate' but 'irregular' or 'erratic'. Therefore, this phenomenon is mostly due to varietal as well as environmental factors in addition to the orchard management practices including pruning, nutrition, irrigation and plant protection.

Though mango is a hardy tree an adverse weather condition can convert an 'on year' into an 'off-year'. The mango cultivated under tropical and subtropical conditions exhibiting different flowering behavior. Therefore, cool temperature is the dominant induction factor, which provides stress that is essentially needed for fruit bud differentiation [3]. If frequent showers occur during 
the period of fruit-bud differentiation (October- November) and flowering (January) with cloudy weather and excessive dew, both flowering and fruit set would be adversely affected. Dry and cool weather with a day /night temperature around $20^{\circ} / 15^{\circ} \mathrm{C}$ during winter season trigger flowering induction.

\section{Genomics}

Research on tree crops is expensive, slow, and has often been focused on limits on production in horticultural species. Recently, the development of genomic and transcriptomic tools has contributed to a better understanding of the metabolic and molecular processes involved in floral biology. Therefore, this complex phenomenon could be solved by transcriptome analysis resulted into numerous differentially expressed genes (DEGs), allowing the partial identification of mechanisms that convert 'on' into 'off' buds [2]. RNA-seq can be used to look for allele specific expression in heterozygous organisms. This is best done with hybrids between very divergence genotypes. This data can be utilized to infer the presence of cis-regulatory variation that influences gene expression levels, to find out regulatory regions and their function in fruit crops. Several candidate genes would be identified in future studies whose differential expression can be correlated with growth habit and architectural variation in another perennial fruit crops. A detailed study is required to coordinate the regulation among chromatin structure, transcription, regulatory genes 'on' and 'off' mechanism and alternative splicing during vegetative to flowering and fruiting transition. Transcriptome profiling is needed for both types of mRNAs and small regulatory RNAs to study the regular and alternate bearing behavior of perennial fruit crops. Fundamental to the task of analyzing gene expression data is the need to select those genes whose patterns of expression are related to a specific phenotype of interest.

On similar aspect work has been done like Nakagawa et al. [4] isolated the FLOWERING LOCUS T-like and gibberellins metabolism genes in biennial-bearing mango trees. They observed the expression of FT, AP1 and LFY in mango, induced in leaves during the flowering induction period. Turktas et al. [5] revealed that nutritional control had a remarkable impact on the alternate bearing of olive, Moreover, hormonal control and flowering processes also played important roles in this phenomenon. Transcript related to flower development (G0243632_1) was altered among the "on" and "off" year leaves. The expression of G0243632_1 was two-fold higher in the "off" year leaves as compared to the "on" year ones in the olive tree. Similarly, Yanik et al. [6] showed the regulation of micro RNA under different developmental phases and tissues indicated that control of nutrition and hormone, together with flowering processes had a noteworthy impact on the olive tree alternate bearing. Shalom et al. [7] had observed that fruit removal resulted in relatively rapid changes in global gene expression, including induction of photosynthetic genes and proteins. Altered regulatory mechanisms included abscisic acid (ABA) metabolism and auxin polar transport. Genes associated with $\mathrm{Ca} 2+$-dependent auxin polar transport were remarkably induced in buds of OFF-Crop and de-fruited trees. Hormone analyses showed that auxin levels were reduced in these buds as compared with $\mathrm{ON}$-crop buds. In mango the availability of the draft genome sequence of is expected to greatly assist future molecular genetic studies, like identification of the complete gene set of regulatory genes, focusing the selection of candidate genes for the final analysis of biological function. Gene expression analyses for flowering in fruit crops allow the identification of genes and the study of their relationship with reproductive processes $[8,9]$.

Understanding the cellular and molecular mechanisms involved in regular and irregular bearing fruit varieties assists in the development of flowering, identification of regulatory regions and factors implicated for regularity in bearing. The information generated will be utilized for identification of potential parents, desired hybrids in early nursery stage, thus would assist breeders by bringing precision breeding and also make available fruits during off years. Hence, there is immense scope of thorough research in this area.

\section{Acknowledments}

Authors are thankful to DST-SERB and ICAR-NPTC for providing the financial assistance and Director ICAR-IARI for research facilities.

\section{References}

1. Monselise SP, Goldschmidt EE (1982) Alternate bearing in fruit trees. Hortic rev 4: 128-173.

2. Sharma N, Singh SK, Singh NK, Srivastav M, Singh BP, et al. (2015) Differential Gene Expression Studies: A Possible Way to Understand Bearing Habit in Fruit Crops. Transcriptomics 3: 110

3. Davenport TL (2007) Reproductive physiology of mango. Braz J Plant Physiol 19(4): 363-376.

4. Turktas M, Inal B, Okay S, Erkilic EG, Dundar E, et al. (2013) Nutrition Metabolism Plays an Important Role in the alternate bearing of the olive tree (Olea europaea L.). PLoS One 8(3): e59876.

5. Nakagawa M, Honsho C, Kanzaki S, Shimizu K, Utsunomiya N (2012) Isolation and expression analysis of flowering locus T-like and gibberellins metabolism genes in biennial-bearing mango trees. Scientia Horticulturae 139: 108-117.

6. Yanik H, Turktas M, Dundar E, Hernandez P, Dorado G, et al. (2013) Genome-wide identification of alternate bearing-associated microRNAs (miRNAs) in olive (Olea europaea L.). BMC Plant Biology 13: 10 .

7. Shalom L, Samuels S, Zur N, Shlizerman L, Zemach H, et al. (2012) Alternate bearing in citrus: changes in the expression of flowering control genes and in Global Gene Expression in 'ON'- versus 'OFF'-Crop Trees. Plos One 7(10): e46930.

8. Shalom L, Samuels S, Zur N, Shlizerman L, Doron-Faigenboim A, et al. (2014) Fruit load induces changes in global gene expression and in abscisic acid (ABA) and indole acetic acid (IAA) homeostasis in citrus buds. Journal of Experimental Botany 65(12): 3029-3044.

9. Singh S (2002) Evaluation of mango cultivars for their flowering, fruiting and fruit quality attributes. Progressive Horticulture 34(2): 240-243. 
This work is licensed under Creative Commons Attribution 4.0 License DOI: 10.19080/CTBEB.2017.07.555707
Your next submission with Juniper Publishers will reach you the below assets

- Quality Editorial service

- Swift Peer Review

- Reprints availability

- E-prints Service

- Manuscript Podcast for convenient understanding

- Global attainment for your research

- Manuscript accessibility in different formats ( Pdf, E-pub, Full Text, Audio)

- Unceasing customer service

Track the below URL for one-step submission https://juniperpublishers.com/online-submission.php 